\title{
Implant Failures in Dentistry: A Review
}

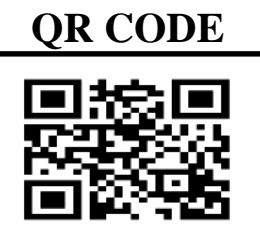

\section{RAVNEET SANDHU', GURNOOR KAUR PANNU²}

Implants have given dentistry a face-lift over the past few decades and the success rates of implants are high. Dental implants are the closest analogue to healthy, natural teeth. They give one the privilege to confidently perform the daily activities and enjoy them, relish the food, laugh and smile with the loved ones without worrying about teeth.(1) Implant placement is a very technique sensitive procedure requiring thorough knowledge as well as an adept implantologist. Despite reliably high success rates, failure of implants can occur neccessitating their immediate removal. Failure can be attributed to numerous causes-failure to osseointegrate being the more common one. The aim of this review is to highlight the major etiology for failure of implants.

KEYWORDS: Implant, Failure, Periimpantitis

\section{INTRODUCTION}

Modern dental implants have been used successfully for over 30 years. They are the strongest devices available to support replacement teeth - and even better, they allow these new teeth to feel, look and function naturally. The history of dental implants has been tracked back to $600 \mathrm{AD}$, when tooth-like pieces of shell were hammered into the jaw of a Mayan woman. 3 million people in the United States have implants, a number that is growing by 500,000 annually. ${ }^{1}$ However, implant failure can occur and is a multifactorial etiology.

Predictors dictating implant success and failure are generally divided into patient-related factors (general patient health status, smoking, quantity and quality of bone, oral hygiene maintenance) implant characteristics (size, additives, loading), implant location, and clinician experience. ${ }^{2,3}$

Diagnosing or identifying an implant is imperative. Implant failure can be of two types: Early or late implant failure. Some causes of early failure are overheating, contamination and trauma during surgery, incorrect immediate load indication, poor bone quantity and/or quality, lack of primary stability so on and so forth. Periimplantitis, occlusal trauma, and overloading are culprits for late implant failure.

Improper selection of patient, poor oral hygiene due to bacterial plaque accumulation, improper prosthetic restoration, debris retention, and bone preparation without the use of coolants have been contributing factors in the breakdown of successfully placed implants. ${ }^{4}$

Over the years a working classification has been compiled for the various causes of implant failure (Table 1).

Surgical conditions: A sterile surgical field plays a very crucial role in success of any surgery be it a restorative procedure or a complex implant placement. Saliva, perioral skin, unsterile instruments, contaminated gloves, operating room air, or air expired by the patient, all interfere in the surgical procedure leading to contamination of the implant site, causing infection in the implant site (nightmare).

Implant characteristics: Short implants, unfavorable crown root ratios are doomed for failure. Similarly, implants whose diameter is small are less apt to withstand stresses leading to fracture of the implant components. Bahat and Handelsman compared the clinical outcomes of the placement of different combinations of implants at one site in the posterior areas and found the failure rate for all $5 \mathrm{~mm}$ implants was $2 \%-3 \%$, and that for all double implants was $1 \%-2 \% .5$ Surface roughness and impurities aid in the retention of an implant and it's success. The characteristics of the implant are important as well the type of bone receiving the implant.

Bone type: Radiographs give a gross idea about the 
quality of the bone available for implant placement however only surgical methods provide the accurate assessment. Posterior mandible and maxilla have type ${ }^{4}$ bone which has very little cortex providing minimal strength in contrast to the thick dense bone in anterior mandible which is conducive for implant placement. Poor bone quality has a negative effect on the primary stabilization of the implant which can be compensated by increasing the number and diameter of fixtures. ${ }^{6}$

Radiation Exposure: Radiation exposure for tumors of the jaw decrease the vascularity of the jaw impairing it's healing potential. This exposure also makes the procedure of implant placement complex. It is best to wait for atleast 1 year after radiation exposure prior to implant placement so as to promote the revascularization and hence the chances of implant success as well. ${ }^{7}$

Smoking: Smoking is a root etiological factor in gingivitis, periodontitis and oral cancers. It causes plaque accumulation. In failure of implants reduced vascularity associated with smoking leads to loss of implant. ${ }^{8}$ Therefore to improve the odds of implant success cessation of smoking should be advised to the patient. A strict cessation protocol is advised before surgical procedure. This cessation regimen should be followed for at least 2 months after the implant placement so protect the initial Osseointegration from the deleterious effects of tobacco and it's derivatives. ${ }^{9}$

General health: Systemic diseases and patient's general health play a very pivotal role in implant success. Late failures are mostly associated with the general medical status of the patient. Diabetes mellitus and osteoporosis have been negatively associated with implant placement success rates. Diabetes mellitus impairs wound healing of the patient, in a similar way it also impairs bone healing following the implant implacement. Owing to this bone healing impairment, failure rate of dental implant in a diabetic patient is much higher than in a non-diabetic patient. ${ }^{10}$ Although only uncontrolled diabetes mellitus is considered a contraindication for the placement of implants. But recently in literature the successful rates of osseointegrated implants in diabetic patients indicate that it is no longer considered to be an absolute contraindication for implant-supported prostheses but only a relative one if the patient's blood sugar is not controlled with inadequate oral hygiene. ${ }^{11}$

Local immune response: There has still been no substantial evidence that related local immune response to implant failures. However, it was found that it might interfere with the maintenance of the same. In subjects with successful implant placement, the titers of $\operatorname{IgG}$ antibody against staphylococcus and Bacteriodes were considerably higher in comparison to those with early implant failure suggesting that humoral immunity factors to these bacteria may be a reason of impaired osseointegration. ${ }^{12}$

Genetics: Gene polymorphism is a process by which a person may exhibit variations within the range which is considered biologically normal. ${ }^{13}$ Polymorphisms have been related to the hypersecretion of several cytokines upon microbiological challenge in certain host- response genes. ${ }^{14,15}$ In the Brazilian population, people with polymorphisms in the IL-616, IL- $4^{17}$ and MMP- ${ }^{18}$ are more susceptible to chronic periodontitis in Caucasians, confirming the role of genetic factors in the pathogenesis of chronic periodontitis. As the inflammatory reaction is related to bone resorption, which is the most key event in the implication of implant failure, further studies are needed for evaluation and establishment of the relationship between early implant failure and gene polymorphisms of inflammatory mediators.

Tissue Abuse and parafunctional habits: Tissue abuse, parafunctional habits, bruxism play a detrimental role in implant success.Tissue abuse , parafunctional habits have been implicated in the progression and genesis of periodontal disease. Parafunctional habits such as bruxism increase the occlusal stress on implants and fracture of implants causing failures. ${ }^{19}$

In a study by Glauser et al., evaluation of 41 patients who received 127 immediately loaded implants was done. The results of the their evaluation showed that implants in patients with a parafunctional habit (patients with bruxism, clenching) were lost more often than those placed in patients with no parafunction ( $41 \%$ vs. $12 \%) .{ }^{20}$ 


\section{CONCLUSION}

Failure of implant has a multifactorial etiology. Several causes are implicated which lead to the ultimate failure of the implant. The clinician needs to identify the main root cause to treat a present condition. Proper history, patient feedback, regular follow up appointments and accurate diagnostic tools will help point out the reason for failure. An early intervention can assist in the better prognosis if there are regular follow up check-ups. The treatment strategy for complications and failing implants depends on the early identification of the failing implants.

\section{REFERENCES}

1. https://www.aaid-implant.org/dental implants/ what-are-dental-implants/[Accessed on $12^{\text {th }}$ April. 2018]

2. Levin L, Schwartz-Arad D. The effect of cigarette smoking on dental implants and related surgery. Implant Dent. 2005;14(4):357- 61.

3. Nitzan D, Mamlider A, Levin L, Schwartz-Arad D. Impact of smoking on marginal bone loss. Int J Maxillofac Implants. 2005;20:605-9.

4. Khatri J,Tated G. Failure in implantology-review article. J Appl Dent Med Sci 2015;1:55-62.

5. Bahat O, Handelsman M. Use of wide implants and double implants in the posterior jaw: A clinical report. Int J Oral Maxillofac Implants 1996;11:379-86 6. Pinto AVS, Miyagusko JM, Ramalho AS, Wassall, T, Pereira LAV. Fatores de risco, complicaçöes e fracassos na terapêutica com implantes osseointegrados. In: Feller, Christa; Gorab, Riad. Atualizaçäo na clínica odontológica: módulos de atualização. São Paulo: Artes Médicas; 200o. p.133216.

7.Jacobsson MG, Jonsson AK, Albrektsson TO, Turesson IE. Short- and long-term effects of irradiation on bone regeneration. Plast Reconstr Surg 1985; 76: 841-50.

8. Misch CE. Early bone loss etiology and its effect on treatment planning. Dent Today 1996; 15: 44-51. 9. Bain CA. Smoking and implant failure-benefits of a smoking cessation protocol. Int J Oral Maxillofac Implants 1996; 11: 756-9.

10. Jadhav RD, Sabane AV, Gandhi PV, Thareja A. Dental implant in diabetic patients: Statement of facts. Indian J Oral Sci 2015;6:47-50.
11. Abdulwassie H, Dhanrajani PJ. Diabetes mellitus and dental implants: a clinical study. Implant Dent 2002; 11: 83-6.

12. Kronstrom M, Svensson B, Erickson E, Houston L, Braham P, Persson G. R. Humoral immunity host factors in subjects with failing or successful titanium dental implants. J Clin Periodontol 2000; 27: 875-82.

13. Thompson, M.W., Mcinnes, R.R., Willard, H.F. Thompson \& Thompson: Genetics in medicine. 5.ed. Philadelphia: Saunders; 1991. pp 500.

14. Shirodaria S, Smith J, McKay IJ, Kennett CN, Hughes FJ. Polymorphisms in the IL-1A gene are correlated with levels of interleukin-1alpha protein in gingival crevicular fluid of teeth with severe periodontal disease. J Dent Res 2000; 79: 1864-9.

15. Pociot F, Molvig J, Wogensen L, Worsaae H, Nerup J. A TaqI polymorphism in the human interleukin-1 beta (IL-1 beta) gene correlates with IL-1 beta secretion in vitro. Eur J Clin Invest 1992; 22: 396-402.

16. Trevilatto PC, Scarel-Caminaga RM, de Brito RB Jr, de Souza AP, Line SR. Polymorphism at position -174 of IL-6 gene is associated with susceptibility to chronic periodontitis in a Caucasian Brazilian population. J Clin Periodontol 2003;30:438-42.

17. Scarel-Caminaga RM, Trevilatto PC, Souza AP, Brito RB Jr, Line SR.Investigation of IL4 gene polymorphism in individuals with different levels of chronic periodontitis in a Brazilian population. J Clin Periodontol. 2003;30:341-345.

18. de Souza AP, Trevilatto PC, Scarel-Caminaga RM, Brito RB, Line SR. MMP-1 promoter polymorphism: association with chronic periodontitis severity in a Brazilian population. J Clin Periodontol. 2003;30(2):154-8.

19. Eswaran MA, Bettie NF, Rai R, Eswaran B, Thillaigovindan R. Failures in endosseous implants - A literature review. Int J Biomed Res 2015;6:75662.

20. Glauser R, Ree A, Lundgren A, Gottlow J, Hammerle $\mathrm{CH}$, Scharer P. Immediate occlusal loading of Br_anemarkimplants applied in various jawbone regions: A prospective,1-year clinical study. Clin Implant Dent Relat Res 2001;3:204-13. 


\section{Cite this article as:}

Sandhu R, Pannu GK. Implant Failures in Dentistry: A Review. Int Healthcare

Source of support: Nil, Conflict of interest: None declared

Res J 2018;2(4):78-81. doi: 10.26440/IHRJ/02_04/179

\section{AUTHOR AFFILIATIONS:}

1. $\quad$ BDS, Private Practitioner, Mohali, Sahibzada Ajit Singh Nagar, Punjab

2. Intern, Rayat Bahra Dental College, Sahibzada Ajit Singh Nagar, Punjab

\section{Corresponding Author:}

Dr. Ravneet Sandhu

House Number 138

Phase 11 SAS Nagar

Mohali-160065
For article enquiry/author contact details, e-mail at: manuscriptenquiry.ihrj@gmail.com

\section{LEGENDS}

\begin{tabular}{|c|c|}
\hline Early failure (intraoperative or within 3 months) & Late failure (postoperative after 3 months) \\
\hline $\begin{array}{l}\text { According to Etiology } \\
\text { - Implant selection : improper implant type or bone } \\
\text { type, length and diameter of the implant, surface } \\
\text { impurity ,surface roughness. } \\
\text { - } \quad \text { Surgical placement: off axis placement, lack of } \\
\text { initial stabilization, overheating of bone, minimal } \\
\text { space between implants, contamination of implants } \\
\text { during placement. } \\
\text { - } \quad \begin{array}{l}\text { Restorative problems: improper design, occlusal } \\
\text { scheme, improper fit, excessive loading, implant } \\
\text { fractures. }\end{array} \\
\text { Due to personnel responsible } \\
\text { - } \quad \begin{array}{l}\text { Dental expertise: oral surgeon, prosthodontist and } \\
\text { periodontist. }\end{array} \\
\text { Laboratory technician: improper design of } \\
\text { According to failure mode: } \\
\text { - Lack of osseointegration. } \\
\text { Due to biological causes } \\
\text { - Peri-implantitis. }\end{array}$ & $\begin{array}{l}\text { According to etiology } \\
\text { - Host factors: systemic factors diabetes, } \\
\text { arthritis, obesity, osteoporosis. } \\
\text { - Tissue abuse: smoking, para functional } \\
\text { habits, alcoholism. } \\
\text { - Radiotherapy. } \\
\text { Due to personnel responsible } \\
\text { - Patient: inadequate post operative } \\
\quad \text { maintenance. } \\
\text { According to failure mode } \\
\text { - Functional and psychological problems. } \\
\text { Due to biological causes } \\
\text { - Infections: retrograde perimplantitis, due to } \\
\quad \text { traumatic occlusion, overloading. }\end{array}$ \\
\hline
\end{tabular}

Table 1. Various Causes of Implant Failure 